\title{
The adherence of Pseudomonas fluorescens to marble, granite, synthetic polymers, and stainless steel
}

\author{
Adesão de Pseudomonas fluorescens em mármore granito, polímeros sintéticos e aço inoxidável
}

\author{
Roberta Torres CARELI ${ }^{1}$, Nelio José ANDRADE ${ }^{1 *}$, Nilda Fatima SOARES ${ }^{1}$, \\ José Ivo Ribeiro JÚNIOR ${ }^{2}$, Marcilía Santos ROSADO ${ }^{1}$, Patrícia Campos BERNARDES ${ }^{1}$
}

\begin{abstract}
The adherence of Pseudomonas fluorescens cells to nine food-processing contact surfaces was evaluated using the plate-count method. The surfaces include marble, granite, stainless steel, polyvinyl chloride, polyurethane, and silicone-coated cloth, which have been used only in a few studies concerning bacterial adherence. The number of cells adhered to the surfaces increased with contact time reaching 5.0-6.1 log $\mathrm{CDM} . \mathrm{cm}^{-2}$ after 10 hours, which can be considered a well established adherence process. The number of adhered cells doubled in $29.5 \mathrm{minutes}$ and 23.5 minutes on stainless steel and thin polyvinyl chloride-coated cloth, respectively. For the other surfaces, this value was 9.8 minutes on average. Marble, granite, thick polyvinyl-coated cloth, double-faced rugous polyurethane, and silicone-coated cloth were not different $(\mathrm{p} \leq 0.05)$ in their ability to adhere cells $\left(\mathrm{CFU} / \mathrm{cm}^{2}\right)$ after 2 and 10 hours. The surfaces that had higher percentage of similarity in the adhesion level and higher $\log \mathrm{CFU} / \mathrm{cm}^{2}$ of adhered cells were double-faced rugous polyurethane, silicone-coated cloth, and granite. The surfaces showed very different microtopography characteristics when viewed using scanning electron microscopy. This experiment showed the importance of using appropriate materials for food contact during processing, which will affect the cleaning and sanitation procedures.

Keywords: bacterial adherence; Pseudomonas fluorescens; marble; granite; synthetic polymers; stainless steel.
\end{abstract}

\section{Resumo}

A adesão de Pseudomonas fluorescens foi avaliada em nove tipos de superfícies de processamento de alimentos por contagem padrão em placas. Superfícies de mármore, granito, aço inoxidável, poli(cloreto de vinila), poliuretano e silicone revestidos com tecido foram avaliadas. O número de células aderidas aumentou com o tempo de contato, alcançando 5,0-6,1 log UFC.cm ${ }^{-2}$ após 10 horas, o qual pode ser considerado um processo de adesão bem estabelecido. O número de células aderidas duplicou em 29,5 minutos em aço inoxidável e 23,5 minutos em poli(cloreto de vinila) revestido com tecido. Nas outras superfícies, em média, esse valor foi 9,8 minutos $\mathrm{p} \geq 0,05$ ) no grau de adesão de células após 2 e 10 horas. As superfícies avaliadas com elevadas porcentagens de similaridade no nível de adesão e contagens de células aderidas foram poliuretano rugoso dupla face, silicone revestido com tecido e granito. As superfícies apresentaram características de microtopografias diferentes quando observadas por microscopia eletrônica de varredura. O experimento mostrou a importância da escolha adequada de materiais para contato com alimentos durante o processamento, os quais irão afetar os procedimentos de limpeza e sanitização.

Palavras-chave: adesão bacteriana; Pseudomonas fluorescens; granito; mármore; polímeros; aço inoxidável bacterial.

\section{Introduction}

There are a few studies on the adherence of pathogens to several surfaces that are extensively used for food processing. For example, marble and granite are commonly used in food services and domestic kitchens, places which have been recently considered responsible for foodborne diseases. There are also some types of polyvinyl chloride (PVC), polyurethane, and silicone, which are bottom face-coated with cloth and have been used as conveyors in several food industries such as fruits and vegetables processors, meat and poultry, bakery, confectionery, and pasta processing, which should be more carefully studied with regards to microbial adherence (LELIEVELD et al., 2005). Microbial adhesion has been evaluated in a large number of food processing contact surfaces including stainless steel, glass, rubber, formic, polypropylene, and polycarbonate (SILVA, et al., 2003; ZAQUEUS et al., 2000). Teflon and cast iron can support microbial growth if a thin layer of food residue is present conditioning the surface to allow bacterial growth (JULLIEN et al., 2002; WONG et al., 2002).

The occurrence of foodborne disease outbreaks has been increasing considerably every year despite the continuous advances in food processing, hygiene, and cleaning and sanitizing procedures. Currently, food safety has been the greatest concern of consumers, food industry, and health public authorities. Food processing contact surfaces have been incriminated as a source of pathogens responsible for foodborne diseases. Under

Recebido para publicação em 14/8/2007

Aceito para publicação em 8/5/2008 (002767)

${ }^{1}$ Grupo de Pesquisa Higiene na Indústria de Alimentos, Departamento de Tecnologia de Alimentos, Laboratório de Higiene e Microbiologia de Alimentos,

Universidade Federal de Viçosa - UFV, Avenida P. H. Rolfs, S/N, CEP 36570-000, Viçosa - MG, Brasil, E-mail: nandrade@ufv.br

${ }^{2}$ Departamento de Informática, Universidade Federal de Viçosa - UFV, Avenida P. H. Rolfs, S/N, CEP 36570-000 Viçosa - MG, Brasil

${ }^{*}$ A quem a correspondência deve ser enviada 
favorable conditions, microorganisms can attach and grow on surfaces and can contaminate the food being processed. Such microorganisms can start microbial adherence and biofilm formation when not removed from the surfaces by adequate cleaning and sanitizing procedures. These occurrences mean that complex microbial communities can contaminate and spoil the food being processed. Microorganisms grow and develop, and when they reach large numbers in the presence of extracellular polymeric substances, biofilm formation is established during food production. Even one single adhered cell can start these processes making it difficult to meet hygiene standards, as the adhered cells are more resistant to detergents and sanitizing actions (WIRTANEN; SALO, 2005).

It has long been recognized that equipment and utensil surfaces can help microorganisms adhere, grow, and become a source of spoilage and pathogenic microorganisms (BEECH, 2004; MIDELET; CARPENTIER, 2004; O’TOOLE et al.; 2000; STOODLEY et al., 2002). Pseudomonas aeruginosa (PARSEK; GREENBERG, 2000; HEYDOM et al., 2002; SAUER et al., 2002), Pseudomonas fluorescens (MASSON et al., 2002; ROSSONI; GAYLARDE, 2000; TYRER et al., 2004; VALCARCE et al., 2002), and Shewanella putrefaciens (HJELM et al., 2002) are members of the spoilage bacteria. Yersinia enterocolitica, Salmonella thyphimurium, (HOOD, 1996; LEJEUNE, 2003), Listeria monocytogenes (BERESFORD et al., 2001; LEJEUNE, 2003), Escherichia coli, Staphylococcus aureus (POMPERMAYER; GAYLARDE, 2000; LEREBOUR et al., 2004), Vibrio parahaemolyticus (WONG et al., 2002), and Klebsiella pneumoniae (DI MARTINO et al., 2003) are included among pathogenic bacteria. Spores of Bacillus cereus (FAILLE et al. 2001; JULLIEN et al., 2002), Bacillus stearothermophilus (FLINT et al., 2001), and Bacillus sporothermodurans (AKUTSU, 2001) are also involved in adherence processes and biofilm formation.

The aim of this research was to evaluate the adhesion of Pseudomonas fluorescens to nine food surfaces used in the food industry, domestic kitchens, and restaurants. In addition, the microtopography of the surfaces was analyzed by scanning electron microscopy.

\section{Materials and methods}

\subsection{Surfaces}

The samples ( $10 \times 10 \times 1 \mathrm{~mm}$ coupon-tests) of food processing contact surfaces evaluated were: marble, granite, polyurethane-coated cloth, double-faced smooth polyurethane, double-faced rugous polyurethane, silicone-coated cloth, thin polyvinyl chloride (PVC) coated cloth, thick PVC-coated cloth, and AISI 304 \#4 stainless steel.

\subsection{Bacterial suspensions and culture media}

Suspensions of Pseudomonas fluorescens ATCC 13525 were used in the experiments. One milliliter of each of these cultures was kept at $-80^{\circ} \mathrm{C}$ in nutrient broth $\left(\mathrm{OXOID}^{\circledR}\right)$ added to glycerol (80:20). A working culture was prepared by inoculating $100 \mu \mathrm{L}$ of the frozen culture into $10 \mathrm{~mL}$ of nutrient broth and incubating at $28^{\circ} \mathrm{C}$ for 24 hours. The culture was sub-cultured three times before use.

\subsection{Attachment of cells}

The coupon tests for $P$. fluorescens attachment were first cleaned by washing with liquid detergent and water, rinsing with distilled water, and immersing them in $70 \%$ ethyl alcohol for 1 hour to remove fat. After that, they were rinsed with distilled water, air-dried, and sanitized by UV exposure of $100 \mu \mathrm{W} . \mathrm{cm}^{-2}$ for 1 hour at $254 \mathrm{~nm}$ (PARIZZI et al., 2004).

The cleaned and sanitized coupons were placed into $250 \mathrm{~mL}$ flasks containing $100 \mathrm{~mL}$ of nutrient broth previously inoculated with suspensions of $P$. fluorescens. The initial number of cells ranged from $10^{3}$ to $10^{4} \mathrm{CFU} . \mathrm{mL}^{-1}$, and the flasks were incubated statically in a water bath at $28^{\circ} \mathrm{C}$. The number of adhered cells on the different surfaces was evaluated by the plate count method after $2,4,6,8$, or 10 hours of contact time. The results were expressed in $\mathrm{CFU} / \mathrm{cm}^{2}$.

\subsection{Counting adhered cells using the plate count method (PCM)}

The coupons with adhered cells were immersed in $10 \mathrm{~mL}$ of $0.1 \%$ peptone water to remove planktonic cells. Then, the coupons were immersed in separated tubes containing $5 \mathrm{~mL}$ of the same solution and swirled in a vortex mixer for 1 minute to release the sessile cells. (PARIZZI et al., 2004). Appropriate dilutions were prepared and transferred to Petri dishes containing Plate Count Agar $\left(\mathrm{OXOID}^{\circledR}\right)$, which were incubated at $28^{\circ} \mathrm{C}$ for 48 hours, and colonies were counted using the method of Swanson et al. (2001). Each colony counted in the plate was equivalent to $2.5 \times 100 \mathrm{UFC} . \mathrm{cm}^{-2}$, as determined by the diluent volume used for rinse $(5 \mathrm{~mL})$, aliquot plated $(0.1 \mathrm{~mL})$, average of colony counting after incubation time $(\mathrm{M})$, decimal dilution, and area of the coupon-test $\left(2 \mathrm{~cm}^{2}\right)$. For this purpose, the following equation was applied (Equation 1):

UFC.cm ${ }^{-2}=\frac{(5 / 1) \times \mathrm{M} \times \mathrm{D}}{2}=2,5 \times \mathrm{M} \times \mathrm{D}$

\subsection{Adherence ratio}

The time in minutes to duplicate the number of adhered cells to surfaces $\left(\mathrm{t}_{\mathrm{a}}\right)$ was calculated using the following Equation 2:

$\mathrm{Y}=\mathrm{kx}+\mathrm{b}$

where $\mathrm{Y}=$ number of adhered cells on surfaces, $\mathrm{x}=$ contact time, $\mathrm{k}=$ velocity of adherence in minutes, and $\mathrm{b}=$ constant (Equation 3):

$a t=\frac{\log 2}{k}$

\subsection{Photomicrography}

The photomicrography of the microorganisms adhered to different surfaces was obtained by using an epifluorescence 
microscope coupled to a computerized image analysis system (PARIZZI et al., 2004).

\subsection{Microtopography surfaces}

To analyze differences in surface microtopographies, photomicrographs of coupons that were not submitted to bacterial adhesion were obtained using Scanning Electron Microscopy (SEM) with a LEO 1430 VP microscope. Double-faced adhesive tape was attached to a stub and a thin layer of colloidal silver was applied to improve electrical conductivity. Then, the coupons were attached to a stub, subjected to a vacuum for metallization (Balzers FDU 010) with a thin gold layer of $20 \mathrm{~nm}$ (to improve electrical conductivity as well), and observed by SEM.

\subsection{Statistical analyses}

Data were analyzed as a split plot design consisting of two treatments - surfaces or contact time. The CFU/ $\mathrm{cm}^{2}$ means of the surfaces were compared by the Scott-Knott test. The results were analyzed by analysis of variance using the Statistical Analysis System - SAEG version 9.0 (Ribeiro Júnior, 2001). The coefficients of linear regressions for contact time were analyzed by the $T$ test at $5 \%$ probability for each surface. A dendrogram based on log CFU $/ \mathrm{cm}^{2}$ means after $2,4,6,8$, and 10 hours was obtained to verify the similarity of adherence in the different surfaces using the SAEG.

\section{Results and discussion}

\subsection{Adherence of P. fluorescens}

P. fluorescens was able to adhere to all surfaces evaluated. Similar to our results, the ability of a number of microorganisms to adhere to different surfaces has been investigated in several studies (AKUTSU, 2001; BERESFORD et al., 2001; DI MARTINO et al., 2003; FLINT et al., 2001; HJELM et al., 2001; LEREBOUR et al., 2004; MASSON et al., 2002; MOREIRA, 2002; PARIZZI et al., 2003; POMPERMAYER; GAYLARDE, 2000; SILVA et al., 2003; TYRER et al., 2004; WONG et al., 2002; ZAQUES et al., 2000).

We found differences in the adherence of $P$. fluorescens depending on the surface and contact time $(p<0.05)$. Linear equations showing the adherence of $P$. fluorescens as a function of contact time for each surface are shown in Table 1. Our findings for the attachment of Listeria innocua to polypropylene, stainless steel, and polycarbonate are close to those observed by Parizzi and co-workers (2004) for the attachment of Listeria innocua to polypropylene, stainless steel, and polycarbonate, and close to those from Silva and co-workers (2003) for the attachment of Escherichia coli and Staphylococcus aureus to low density polyethylene.

As shown in Table 2, the number of adhered cells increased as a function of time as expected ranging between $1.6 \log \mathrm{CFU} / \mathrm{cm}^{2}$ on stainless steel surfaces after 2 hours and $6.1 \mathrm{log} \mathrm{CFU} / \mathrm{cm}^{2}$ on marble and granite surfaces after 10 hours.

After 4 and 6 hours of contact time, silicone-coated cloth, double-faced rugous polyurethane, granite, and polyurethanecoated cloth surfaces showed higher adherence. After 6 hours, the number of adhered cells reached $4.8 \log \mathrm{CFU} / \mathrm{cm}^{2}$ on granite and polyurethane-coated cloth, and after 8 hours this value was $5.5 \log \mathrm{CFU} / \mathrm{cm}^{2}$ on granite (Table 2).

Marble, granite, thick polyvinyl chloride-coated cloth, double-faced rugous polyurethane, and silicone-coated cloth did not show differences $(\mathrm{p}>0.05)$ in $\log \mathrm{CFU} / \mathrm{cm}^{2}$ after 2 and 10 hours (Table 2 ).

After 10 hours, stainless steel $\left(5.0 \log \mathrm{CFU} / \mathrm{cm}^{2}\right)$, doublefaced smooth polyurethane $\left(5.0 \log \mathrm{CFU} / \mathrm{cm}^{2}\right)$, and thin PVC chloride-coated cloth $\left(5.1 \log \mathrm{CFU} / \mathrm{cm}^{2}\right)$ surfaces showed the lowest number of adhered cells, which were different $(p>0.05)$ from the other surfaces (Table 2).

\subsection{Ratio of adherence}

There were significant differences $(\mathrm{p}<0.05)$ in the ratio of adherence which means difference in the time (minutes) for

Table 1. Adherence of Pseudomonas fluorescens, growing in nutrient broth at $28^{\circ} \mathrm{C}$, to different surfaces evaluated by the plate count method.

\begin{tabular}{|c|c|c|}
\hline Surfaces & Equations & $\mathrm{R}^{2}(\%)$ \\
\hline SS & $\hat{\mathrm{Y}}=0.874+0.402 * \mathrm{TC}$ & 99.31 \\
\hline $\mathrm{PU}_{\mathrm{DFS}}$ & $\hat{\mathrm{Y}}=1.371+0,402 * \mathrm{TC}$ & 96.45 \\
\hline PUcc & $\hat{\mathrm{Y}}=2.132+0,365 * \mathrm{TC}$ & 94.95 \\
\hline $\mathrm{PU}_{\mathrm{DFR}}$ & $\hat{\mathrm{Y}}=2.387+0.361 * \mathrm{TC}$ & 99.80 \\
\hline $\mathrm{PVC}_{\mathrm{TCC}}$ & $\hat{\mathrm{Y}}=0.773+0.455^{\star} \mathrm{TC}$ & 95.59 \\
\hline $\mathrm{PVC}_{\mathrm{TCT}}$ & $\hat{\mathrm{Y}}=1.710+0.414 * \mathrm{TC}$ & 99.18 \\
\hline $\mathrm{SIL}_{\mathrm{cc}}$ & $\hat{\mathrm{Y}}=2.276+0.374 * \mathrm{TC}$ & 98.10 \\
\hline GRA & $\hat{\mathrm{Y}}=2.052+0.422 * \mathrm{TC}$ & 99.04 \\
\hline MAR & $\hat{\mathrm{Y}}=1.585+0.451 * \mathrm{TC}$ & 99.24 \\
\hline
\end{tabular}

${ }^{*}$ Significant at $5 \%$ of probability level by $F$ test $(\mathrm{p}<0.05) ; \hat{\mathrm{Y}}=\log \mathrm{CFU} / \mathrm{cm}^{2}$; $\mathrm{CT}=$ contact time (hours); $\mathrm{SS}=$ stainless steel $; \mathrm{PU}_{\mathrm{DFS}}=$ double-faced smooth polyurethane; $\mathrm{PUcc}=$ polyurethane coated with cloth; $\mathrm{PU}_{\mathrm{DFR}}=$ double-faced rugous polyurethane; $\mathrm{PVC}_{\mathrm{TCC}}=$ polyvinyl chloride thin coated with cloth $\mathrm{PVC}_{\mathrm{CTC}}=$ polyvinyl chloride coated with thick cloth; $\mathrm{SIL}_{c c}=$ silicon coated with cloth; GRA = granite; and MAR = marble

Table 2. Log CFU/ $\mathrm{cm}^{2}$ of Pseudomonas fluorescens ATCC 13525 adhered to nine food contact processing surfaces after growing in nutrient broth at $28{ }^{\circ} \mathrm{C}$ and incubated for different Contact Time (CT), as evaluated by the plate count method.

\begin{tabular}{llllll}
\hline Surface & $\mathrm{CT}_{2}$ & $\mathrm{CT}_{4}$ & $\mathrm{CT}_{6}$ & $\mathrm{CT}_{8}$ & $\mathrm{CT}_{10}$ \\
\hline SS & $1.6^{\mathrm{b}}$ & $2.6^{\mathrm{c}}$ & $3.2^{\mathrm{c}}$ & $4.0^{\mathrm{c}}$ & $5.0^{\mathrm{b}}$ \\
PU $_{\text {DFS }}$ & $1.9^{\mathrm{b}}$ & $3.1^{\mathrm{b}}$ & $3.9^{\mathrm{b}}$ & $4.8^{\mathrm{b}}$ & $5.0^{\mathrm{b}}$ \\
PUCC & $2.7^{\mathrm{a}}$ & $3.5^{\mathrm{a}}$ & $4.8^{\mathrm{a}}$ & $5.1^{\mathrm{b}}$ & $5.6^{\mathrm{b}}$ \\
PU $_{\text {DFR }}$ & $3.1^{\mathrm{a}}$ & $3.9^{\mathrm{a}}$ & $4.6^{\mathrm{a}}$ & $5.3^{\mathrm{a}}$ & $5.9^{\mathrm{a}}$ \\
PVC $_{\text {TCC }}$ & $1.8^{\mathrm{b}}$ & $2.6^{\mathrm{c}}$ & $3.2^{\mathrm{c}}$ & $4.9^{\mathrm{b}}$ & $5.1^{\mathrm{b}}$ \\
PVC $_{\text {CTC }}$ & $2.7^{\mathrm{a}}$ & $3.2^{\mathrm{b}}$ & $4.2^{\mathrm{b}}$ & $5.0^{\mathrm{b}}$ & $5.9^{\mathrm{a}}$ \\
SIL $_{\text {CC }}$ & $2.8^{\mathrm{a}}$ & $3.9^{\mathrm{a}}$ & $4.7^{\mathrm{a}}$ & $5.3^{\mathrm{a}}$ & $5.9^{\mathrm{a}}$ \\
GRA $_{\text {MAR }}$ & $2.8^{\mathrm{a}}$ & $3.8^{\mathrm{a}}$ & $4.8^{\mathrm{a}}$ & $5.5^{\mathrm{a}}$ & $6.1^{\mathrm{a}}$ \\
\hline
\end{tabular}

Averages followed by the same lower case letter in the column did not differ according to the Scot-Knott test $(\mathrm{p}>0.05)$. SS = stainless steel; $\mathrm{PU}_{\mathrm{DFS}}=$ double-faced smooth polyurethane; $\mathrm{PUCC}=$ polyurethane coated with cloth; $\mathrm{PU}_{\mathrm{DFR}}=$ double-faced rugous polyurethane; $\mathrm{PVC}_{\mathrm{TCC}}=$ polyvinyl chloride thin coated with cloth $\mathrm{PVC}_{\mathrm{CTC}}=$ polyvinyl chloride coated with thick cloth; SIL $_{c c}=$ silicon coated with cloth; GRA = granite; and MAR $=$ marble 
doubling the number of cells adhered to surfaces. A higher ratio of adherence was observed for stainless steel and thin polyvinyl chloride-coated cloth (Table 3) reaching 29.5 minutes and 23.5 minutes, respectively. In addition, these surfaces showed the lowest number of adhered cells after the evaluated contact time, except after 8 hours (Table 2). There were no differences $(p \geq 0.05)$ in the ratio of adherence for the other surfaces. In those surfaces, the number of adhered cells doubled, on average, after 9.8 minutes.

The dendrogram (Figure 1) shows the similarity between the surfaces used for evaluating the adhesion of $P$. fluorescens and the similarity of surface groups concerning the number of adhered cells.

Table 3. Ratio of adherence* (minutes) of Pseudomonas fluorescens to different surfaces.

\begin{tabular}{lcc}
\hline Surfaces & \multicolumn{2}{c}{ Ratio of adherence (minutes) } \\
\hline SS & 29.50 & $\mathrm{a}$ \\
PU $_{\text {DFS }}$ & 13.38 & $\mathrm{~b}$ \\
PUcC & 8.58 & $\mathrm{~b}$ \\
PU $_{\text {DFR }}$ & 7.45 & $\mathrm{~b}$ \\
PVC $_{\text {TCC }}$ & 23.50 & $\mathrm{a}$ \\
PVC $_{\text {CTC }}$ & 10.56 & $\mathrm{~b}$ \\
SIL $_{\text {CC }}$ & 8.10 & $\mathrm{~b}$ \\
GRA & 9.01 & $\mathrm{~b}$ \\
MAR & 11.41 & $\mathrm{~b}$ \\
\hline
\end{tabular}

${ }^{\star}$ Time for doubling the bacterial population.

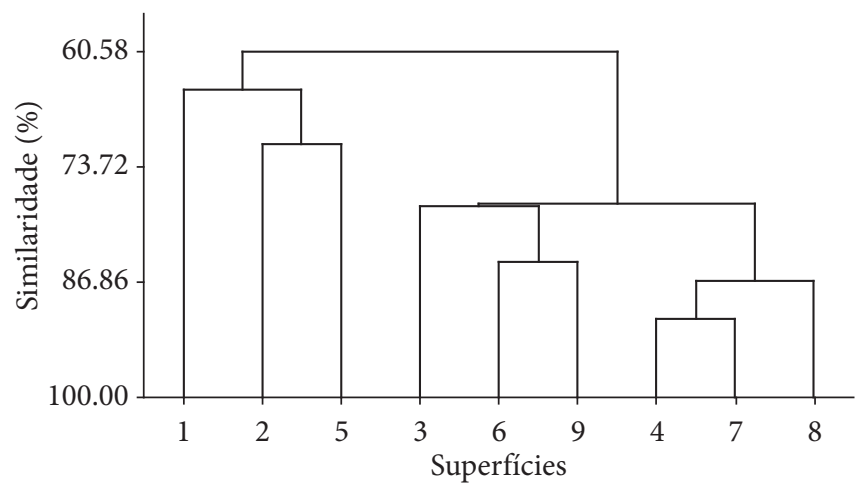

1 - Stainless steel

2 - Double-faced smooth polyurethane

3 - Polyurethane coated with cloth

4 - Double-faced rugous polyurethane

5 - Polyvinyl chloride thin coated with cloth

6 - Polyvinyl chloride coated with thick cloth

7 - Silicon coated with cloth

8 - Granite

9 - Marble

Figure 1. Dendrogram of Pseudomonas fluorescens ATCC 13525 adherence to nine food processing contact surfaces by the plate count method (expressed in $\log \mathrm{CFU} / \mathrm{cm}^{2}$ ).

\subsection{Similarity in adherence ability}

The nine surfaces were clustered in three groups according to similarities in adherence ability (Figure 1 and Table 3 ). The first group was composed of stainless steel, double-faced smooth polyurethane, and thin polyvinyl chloride-coated cloth, with $65 \%$ similarity and a mean of $3.5 \log$ UFC. $\mathrm{cm}^{-2}$. The second group included surfaces of polyurethane with cloth, thick polyvinyl-coated cloth, and marble, with $78 \%$ similarity and a mean of $4.27 \log \mathrm{CFU} / \mathrm{cm}^{2}$. The third group was composed of double-faced rugous polyurethane, silicone-coated cloth, and granite, with $87 \%$ similarity and mean of $4.55 \log \mathrm{CFU} / \mathrm{cm}^{2}$. According to the PCM, double-faced rugous polyurethane, silicone-coated cloth, and granite showed a higher percentage of similarity and higher means of adhered cells.

The Scott-Knott test and the similarity test did not show good agreement. Only the surfaces included in group III (Table 3), according to the similarity test, were not different according to the Scott-Knott test ( $\mathrm{p}>0.05)$.

A few studies in the literature focus on the adherence process of marble and granite. Several microbial species were isolated from these surfaces in healthcare services including Bacillus spp., Pseudomonas aeruginosa, Pseudomonas fluorescens, Staphylococcus aureus, Staphylococcus epidermidis, Staphylococcus haemoliticus, Proteus vulgaris and Shigella sonne. Pseudomonas aeruginosa (15\%) and Staphylococcus haemoliticus (15\%) were found to be the main microorganisms adhered to surfaces (MOREIRA, 2002). The other microorganisms were responsible for $70 \%$ of the adhesion observed.

\subsection{Surface microtopography}

Figure 2 illustrates the microtopography and bacterial cells adhered to marble and granite surfaces. Some surface imperfections, as shown by scanning electron microscopy, were large enough to hold and protect $P$. fluorescens bacterial cells which are straight and rod-shaped with dimensions of $0.5-1.0 \mu \mathrm{m} \times 1.5-5.0 \mu \mathrm{m}$ (HOLT et al. 1994). Before this experiment, commercial sample surfaces were not submitted to chemical agents such as detergents and sanitizers commonly applied in hygiene procedures. It is known that chemicals such as acids, alkalis, or oxidants cause abrasion and increase the microscopic porosity of rock surfaces such as granite and marble. These materials are considerably damaged by use over time. Figure 2 shows the surfaces of granite and marble as observed by SEM. These surfaces are extremely rough showing the presence of cracks and crevices, undulations and depressions $(26.46 \mu \mathrm{m}$, Figure $2 \mathrm{a})$ in diameter, Figure $2 \mathrm{a})$, and pores (6.118 and $13.44 \mu \mathrm{m}$ in length, Figure $2 \mathrm{c}$ ). Figures $2 \mathrm{~b}$ and $2 \mathrm{~d}$ show the adherence of Pseudomonas fluorescens to granite and marble as seen under epifluorescence microscopy.

These results confirm the importance that must be given to the choice of material for equipment, utensils, and tables used in food processing. The choice of surfaces with the most appropriate characteristics is crucial for controlling the adherence process and biofilm formation. Effective control of cleaning and sanitizing procedures can possibly avoid or minimize food spoilage and outbreaks of foodborne diseases. 

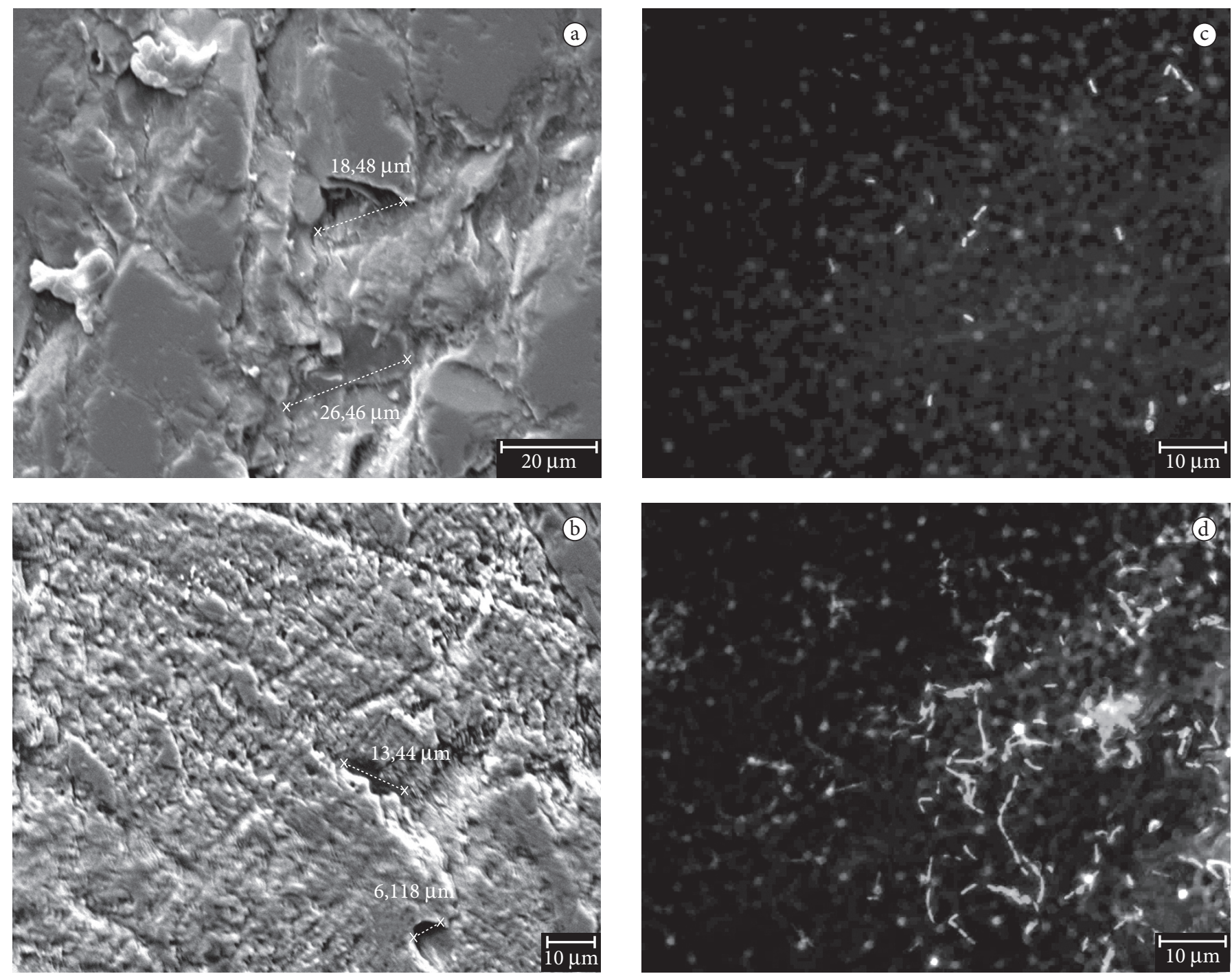

Figure 2. Photomicrography of Pseudomonas fluorescens ATCC 13525 adhered to granite and marble after growing for 2 and 8 hours respectively, in nutrient broth at $28^{\circ} \mathrm{C}$. a) Microtopography of granite surface; b) adhered cells after 2 hours; c) microtopography of marble surface; and d) dhered cells after 8 hours.

\section{Conclusions}

All surfaces showed adherence of Pseudomonas fluorescens, reaching a maximum of $6.1 \log \mathrm{CFU} / \mathrm{cm}^{2}$. Marble and granite surfaces showed high porosity, cracks, crevices, undulations, and depressions large enough to hold and anchor high numbers of adhered cells, as observed under epifluorescence microscopy and scanning electron microscopy.

A higher adherence ratio was observed for stainless steel and thin polyvinyl chloride-coated cloth reaching 29.5 and 23.5 minutes, respectively. For the other surfaces, the adherence ratio mean was 9.8 minutes.

Surfaces coated with cloth showed occurrences of protuberances, elevations, microholes, cloth fraying, non-smooth surfaces, undulations and depressions with different diameters, and the occurrence of air bubbles due to protuberance defects that supported microbial growth. This resulted in a high number of adhered cells on all surfaces, which can be considered an adherence process.

\section{Acknowledgements}

The authors are grateful for the financial support provided by the foundations CAPES (Brazilian research supporting foundation) and $\mathrm{CNPq}$ (The National Council for Scientific and Technological Development).

\section{References}

AKUTSU, C. K. Adesão de esporos de Bacillus sporothermodurans ao aço inoxidável e sua resistência a sanificantes químicos em condições de uso simulado. Viçosa, 2001. 60 p. Dissertação 
(Mestrado em Ciência e Tecnologia de Alimentos) - Universidade Federal de Viçosa - UFV.

BEECH, I. B. Corrosion of technical materials in the presence of biofilms - current understanding and state of the art methods of study. International Biodeterioration \& Biodegradation, v. 53, n. 3, p. 177-183, 2004.

BERESFORD, M. R.; ANDREW, P. W.; SHARMA, G. Listeria monocytogenes adheres to many materials found in food-processing environments. Journal of Applied Microbiology, v. 90, n. 1, p. $1000-1005,2001$

CARPENTIER, B.; CHASSAING, D. Interactions in biofilms between Listeria monocytogenes and resident microorganisms from food industry premises. International. Journal of Food Microbiology, v. 97, n. 2, p. 111-122, 2004.

DI MARTINO, P. et al. Klebsiella pneumoniae type 3 pili facilitate adherence and biofilm formation on abiotic surfaces. Research in Microbiology, v. 154, n. 1, p. 9-16, 2003.

FAILLE, C.; FONTAINE, F.; BÉNÉZECH, T. Potential occurrence of adhering living spores in milk product processing lines. Journal of Applied Microbiology, v. 90, n. 6, p. 892-900, 2001.

FLINT, S. et al. The growth of Bacillus stearothermophilus on stainless steel. Journal of Applied Microbiology, v. 90, n. 2, p. 151-157, 2001.

HEYDOM , A. et al. Statistical analysis of Pseudomonas aeruginosa biofilm development: impact of mutations in genes involved in twitching motility, cell-to-cell signaling and stationary-phase $\alpha$ factor expression. Applied and Environmental Microbiology, v. 68, n. 4, p. 2008-2017, 2002.

HJELM, M. et al. Comparison of adhesion of the food spoilage bacterium Shewanella putrefaciens to stainless steel and silver surfaces. Journal of Applied Microbiology, v. 92, n. 5, p. 903-911, 2002.

HOLT, J. G. et al. Bergey's manual of systematic bacteriology. 9 ed. Baltimore: Willians e Wilkins, 1994.

JULLIEN, C. et al. Identification of surface characteristics relevant to the hygienic status of stainless steel for the food industry. Journal of Food Engineering, v. 56, n. 1, p. 77-87, 2002.

LEJEUNE, P. Contamination of abiotic surfaces: what a colonizing bacterium sees and how to blur it. Trends in Microbiology, v. 11, n. 4, p. 179-184, 2003.

LEREBOUR, G.; CUPFERMAN, S.; BELLON-FONTAINE, M. N. Adhesion of Staphylococcus aureus and Staphylococcus epidermidis to the Episkin ${ }^{\circledast}$ reconstructed epidermis model and to an inert 304 stainless steel substrate. Journal of Applied Microbiology, v. 97, n. 1, p. 7-16, 2004.

LILIEVELD, H. L. M..; MOSTERT, M. A.; HOLAH, J. Handbook of hygiene control in the food industry. Cambrige, England: CRC Press, 2005. $720 \mathrm{p}$.

MASSON, Y. et al. Growth of Pseudomonas fluorescens and Candida sake in homogenized mushrooms under modified atmosphere. Journal of Food Engineering, v. 54, n. 2, p. 125-131, 2002.

MIDELET, G.; CARPENTIER, B. Impact of cleaning and disinfection agents on biofilm structure and on microbial transfer to a solid model food. Journal of Applied Microbiology, v. 97, n. 2, p. 97, 262-270, 2004.
MOREIRA, L. R. C. Bancadas hospitalares: Superfícies e porosidades como fontes potenciais de infecção. São José dos Campos, 2002. 91p. Dissertação (Mestrado em Engenharia Biomédica) Universidade do Vale do Paraíba - UNIVAP.

O’TOOLE, G. A.; KAPLAN, H. B., KOLTER, R. Biofilm formation as microbial development. Annual Review of Microbiology, v. 54, n. 1, p. 187-209, 2000.

PARIZZI, S. Q. F.; ANDRADE, N J. Bacterial adherence to different inert surfaces evaluated by epifluorescence microscopy and plate count method. Brazilian Archives of Biology and Technology, v. 47, n. 1, p. 77-83, 2004.

PARSEK, M. R.; GREENBERG, E. P. Acyl homoserine lactone quorum sensing in Gram negative bacteria: a signaling mechanism involved in associations with higher organisms. Proceedings of the National Academy of Sciences, v. 97, n. 16, p. 8789-8793, 2000.

POMPERMAYER, D. M. C.; GAYLARDE, C. C. The influence of temperature on the adhesion of mixed cultures of Staphylococcus aureus and Escherichia coli to polypropylene. Food Microbiology, v. 17, n. 4, p. 361-365, 2000.

RIBEIRO JÚNIOR, J. I. Análises estatísticas no SAEG. Viçosa: Editora Folha de Viçosa, 2001.

ROSSONI, E. M. M.; GAYLARDE, C. C. Comparison of sodium hypochlorite and peracetic acid as sanitising agents for stainless steel food processing surfaces using epifluorescence microscopy. International Journal of Food Microbiology, v. 61, n. 1, p. 81-85, 2000.

SAUER, K. et al. Pseudomonas aeruginosa displays multiple phenotypes during development as biofilm. Journal of Bacteriology, v. 184, n. 4, p. 1140-1154, 2002.

SILVA, C. A. S. et al. Evaluation of ultraviolet radiation to control microorganisms adhering to low-density polyethylene films. Brazilian Journal of Microbiology, v. 34, n. 2, p. 175-178, 2003.

STOODLEY, P. et al. Biofilms as complex differentiated communities. Annual Review of Microbiology, v. 56, n. 1, p. 187-209, 2002.

SWANSON, K. M. J.; PETRAN, R. L.; HANLIN, J. H. Culture Methods for Enumeration of Microrganisms. In: DOWNES, F. P.; ITO, K. (Eds.). Compendium of methods for the microbiological examination of foods. 4 ed. [S.L.]: APHA, 2001. cap. 5, p. 53-62.

TYRER, H. et al. Modelling the growth of Pseudomonas fluorescens and Candida sake in ready-to-eat meals. Journal of Food Enginnering, v. 65 , n. 1, p. 137-143, 2004.

VALCARCE, M. B. et al. The influence of the surface condition on the adhesion of Pseudomonas fluorescens (ATCC 17552) to copper and aluminium brass. International Biodeterioration \& Biodegradation, v. 50, n. 1, p. 61-66, 2002.

WIRTANEN, G.; SALO, S. Biofioms risks. In: LILIEVELD, H. L. M.; MOSTERT, M. A.; HOLAH, J. Handbook of hygiene control in the food industry. Cambrige, England: CRC Press, 2005. p 46-62.

WONG, H.; CHUNG, Y.; YU, J. Attachment and inativation of Vibrio parahaemolyticus on stainless steel and glass surface. Food Microbiology., v. 19, n. 4, p. 341-350, 2002.

ZAQUEUS, O. M. et al. Bacterial biofilm formation on polyvinyl chloride, polyethylene and stainless steel exposed to ozonated water. Water Research, v. 34, n. 1, p. 63-70, 2000. 